\title{
OPERATIONAL PERFORMANCE OF AN AGRICULTURAL TRACTOR AS A FUNCTION OF WEIGHT, INFLATION PRESSURE AND TIRE LIFE
}

\author{
Roger Toscan Spagnolo ${ }^{1}$, Marcos Antonio Zambillo Palma ${ }^{2}$, Carlos Eduardo Silva Volpato ${ }^{3}$, Jackson Antonio \\ Barbosa $^{4}$, Rodrigo Alencar Nunes ${ }^{5}$
}

\begin{abstract}
The main objective of this study was to evaluate the operating performance of an agricultural tractor operating with new and worn tires for distinct tire weight conditions and three inflation pressures. The tests were conducted at the experimental unit of the Department of Animal Science, Federal University of Lavras, with average soil moisture of $25.6 \%$ and $14.97 \mathrm{t} \mathrm{ha}^{-1}$ dry matter at the time of testing. The $4 \times 2$ TDA tractor was used with an engine output of 65.62 kW (88 HP). The tires were R1 type with the following features: diagonal (front: 12.4-24, rear: 18.4-30), where the average tread heights of the new tire were 30 and $35 \mathrm{~mm}$ for front and rear tires respectively, while the worn tires measured $18 \mathrm{~mm}$ and $4.5 \mathrm{~mm}$, respectively. The experimental design was setup in randomized blocks arranged in a $2 \times 3 \times 3$ factorial arrangement, with 18 treatments and 3 replications. The results showed advantages for the tractor equipped with new tires. Slip was greater when using new tires due to increased strength and power in the drawbar.
\end{abstract}

Keywords: skating, strength, power, traction coefficient

\section{RESUMO}

\section{DESEMPENHO OPERACIONAL DE UM TRATOR AGRÍCOLA EM FUNÇÃO DA LASTRAGEM, PRESSÃO DE INFLAÇÃO E DESGASTE DO PNEU}

Objetivou-se com o presente trabalho avaliar o desempenho operacional de um trator agrícola operando com pneus novos e desgastados em três condições de lastragem e três pressões de inflação dos pneus. O experimento foi realizado na unidade experimental pertencente ao Departamento de Zootecnia da Universidade Federal de Lavras, apresentando teor de água do solo de 25,6\% e 14,97 $\mathrm{T} \mathrm{ha}^{-1}$ de matéria seca no momento da realização dos testes. Utilizou-se um trator $4 \times 2$ TDA, com potência de $65,62 \mathrm{~kW}$ ( $88 \mathrm{HP}$ ) no motor. Os pneus foram do tipo R1, com as seguintes características: diagonal (dianteiros: 12.4-24; traseiros: 18.4-30), sendo que, a altura média das garras dos pneus novos foi de 30 e 35 $\mathrm{mm}$ para os pneus dianteiros e traseiros respectivamente, enquanto os pneus desgastados as garras mediram $18 \mathrm{~mm} \mathrm{e}$ $4,5 \mathrm{~mm}$, respectivamente. O delineamento experimental foi de blocos casualizados, em esquema fatorial $2 \times 3 \times 3$, com 18 tratamentos e 3 repetições. Os resultados evidenciaram vantagens para o trator quando equipado com pneus novos. A patinagem foi maior quando usado pneus novos devido ao aumento da força e potência na barra de tração.

Palavras-chaves: patinagem, força, potência, coeficiente de tração.

\section{Recebido para publicação em 20/02/2013. Aprovado em 27/05/2013.}

1 - Eng. Agrícola, Doutorando em Agronomia, Dep. de Eng. Rural/DER, UFPel, Capão do Leão - RS, rogertoscan@yahoo.com.br 2 - Eng. Agrícola, Doutorando em Enga Agrícola, Dep. de Engenharia/DEG, UFLA, Lavras - MG, markospalma@gmail.com

3 - Eng. Florestal, Doutor em Enga Agrícola, Professor, Dep. de Engenharia/DEG, UFLA, Lavras - MG, volpato@ufla.br

4 - Eng. Agrícola, Doutor em Enga Agrícola, Professor, Dep. de Engenharia/DEG, UFLA, Lavras - MG, jackson_barbosa@hotmail.com 5 - Engenheiro Agrícola, Dep. de Engenharia/DEG, UFLA, Lavras - MG, nunes.engagricola@gmail.com 


\section{INTRODUCTION}

In agricultural tires, the incorrect inflation pressure is the factor that most contributes to the development of premature damage and wear. Overloading and inflation pressure below the specification results in greater bending on the sides, causing the tread area to present premature and uneven wear. However, for pressures above specification causes deficient bending of the tread area, resulting in an increase of wear on the central part of the tire. Furthermore, the contact area of the tire with the ground diminishes, resulting in loss of traction, increased spinning and fuel consumption (SMERDA; CUPERA, 2010; SPAGNOLO et al. 2012).

According to Yanai et al. (1999), tire characteristics that affect operational performance of the tractor are construction type, tread area configuration, wheel width and the diameter and normal load on drive wheels. Among the soil properties that affect the efficiency and operating performance of an agricultural tractor, those most important are soil texture, moisture and surface conditions, depending on each type of existing ground cover (GABRIEL FILHO et al., 2004; SALVADOR et al., 2009).

Serrano et al. (2003) reported that adequate interaction between pressure and the ballast shall resulted in spinning values within an acceptable interval, normally 5 to $15 \%$. A spinning index of $20 \%$ is used by some authors (GEE-CLOUGH et al., 1977; DWYER; FEBO, 1987) to express the net traction coefficient when the objective is to compare the performance of tires in the field. The index of $30 \%$ represents a situation of extreme loss of energy by the tire, which is not impossible to be found in agricultural operations.

Yanai et al. (1999) used a tractor with auxiliary front-wheel drive, diagonal tires in tests performed in field condition of immobilized soil, applying four distinct loads on the rear and front tires respectively (31.46-19.84; 30.47-18.00; 29.07-16.62; 27.98$15.03 \mathrm{kN}$ ), and four levels of pressure on the rear and front tires respectively (193-165; 165-138; $138-110$ and $110-83 \mathrm{kPa}$ ). The results showed that the reduction on total ballast from $51.28 \mathrm{kN}$ to $43.01 \mathrm{kN}$ caused a reduction of $14.5 \%$ in spinning and $15 \%$ in the traction coefficient. The interaction between inflation pressure and load on the tire has indicated that certain combinations of these two factors $(51.28 \mathrm{kN} ; 138 \mathrm{kPa})$ and $(51.28 \mathrm{kN} ; 165$ $\mathrm{kPa}$ ) were most favorable for the development of greater displacement speed and less spinning.

The drawbar power tends to increase as a function of spinning until it reaches a maximum level, which further decreases with the increase in spinning, as stated by Corrêa et al. (1997) who found maximum drawbar power $(21.62 \mathrm{~kW})$ at $25 \%$ spinning during which the tractor operated with a set of radial tires on a soil with remainders of corn cropping. On the other hand, for planted soil the maximum drawbar power was $26.60 \mathrm{~kW}$ with a spinning index of $15 \%$.

Gabriel Filho et al. (2010) compared the performance of a tractor equipped with new and worn diagonal tires on three surface conditions: mobilized soil, mulch and firm soil. In function of the wear of the front $(63.4 \%)$ and rear tires $(41.2 \%)$, the result of the average speed on mobilized soil was greater for the new tire than the average speed of the worn tire, because spinning of the front and rear axles with worn tires was greater. For the track with mulching, the worn tires presented values $3.32 \%$ greater for speed, $8.45 \%$ less for hourly fuel consumption and $1.80 \%$ greater for power available on the drawbar. For the track with firm soil the results for the worn tires were 3.65\% greater for speed, $38.65 \%$ less for spinning of the front axles, $23.22 \%$ less for the spinning of the rear axles, $12.73 \%$ less for hourly fuel consumption and $3.60 \%$ greater for power available on the drawbar.

Ferreira et al. (2000b) studied the effect of the internal tire pressure on distinct surface conditions with respect to traction drawbar force of a $4 \times 2$ tractor with diagonal traction agricultural tires and concluded that, for the condition of loose soil, the greater traction force occurs with the greater internal pressures of the tires, regardless of the load to be handled by the tractor. Meanwhile, in conditions of firm soil, the tractor handles larger loads with low tire pressure, thus its traction capability is greater.

In agricultural production it is estimated that more than half of the time consumed is used in transportation activities, where the agricultural tractor is the main driving element and is also used for dragging field implements, thus the 
transformation of motor power into traction power must be as efficient as possible. Any potential improvement with regards to performance of traction devices therefore directly contributes to the efficiency of agricultural production and for the conservation of fossil fuel power (BARBOSA et al., 2005).

The present work was carried out with the objective of assessing the operating performance of an agricultural tractor with auxiliary front-wheel drive, considering tire tread area wear, pressure and ballast factors.

\section{MATERIALS AND METHODS}

Tests were performed in the experimental unit of the Zootechnics Department of the Federal University of Lavras, located in the city of Lavras, MG, Brazil, located at the coordinates $21^{\circ} 13^{\prime} 50^{\prime \prime}$ latitude south and $44^{\circ} 57^{\prime} 52^{\prime \prime}$ longitude west, and elevation of $917 \mathrm{~m}$. The soil is classified as typically clayey Distroferric Red Latossoil (LVdf), with slope of $4.98 \%$. The area was previously used as a brachiaria pasture for more than 8 years, with average population of two animals per hectare, presenting a firm agricultural soil surface condition with mulching and no preparation, which was mowed before the experiment was performed. Soil samples were collected for its characterization regarding texture and moisture. Data referring to penetration resistance and amount of organic matter present on the soil surface were also collected.

The experiment was conducted in 54 randomized plots in a $2 \times 3 \times 3$ factorial design (two levels of tire wear, three levels of inflation pressure and 3 levels of ballast), totaling 18 treatments and 3 repetitions. The two sets of tires used were diagonals, one regarded as new and the other as worn, where the new tires had average tread heights of 0.03 and $0.035 \mathrm{~m}$, and the worn tires 0.0045 and 0.018 $\mathrm{m}$ for the front and rear tires, respectively. Each test area consisted of $90 \mathrm{~m}^{2}(30 \times 3 \mathrm{~m})$ and a 15 $\mathrm{m}$ longitudinal space was left between plots for machine maneuvering and traffic.

The test tires were mounted on a 4X2Valtra BL 88 series agricultural tractor, with auxiliary frontwheel drive (TDA), $65.62 \mathrm{~kW}(88 \mathrm{CV})$ nominal engine power, total weight with ballast of 45.24 $\mathrm{kN}$ (4613 kgf), distributed as 38\% on the front axle and $62 \%$ on the rear axle. The tractor operated in second reduced gear at an engine rotation of 1750 $\mathrm{rpm}$, with the auxiliary front-wheel drive engaged. For obtaining the traction drawbar force and spinning, a Massey Fergusson model 290 brake tractor was used, with total weight of $39.06 \mathrm{kN}$ (3983 kgf), which worked in second reduced gear at engine speed of $1750 \mathrm{rpm}$.

Two sets of diagonal tires were used on the tractor, one considered new and the other worn. The new tires used on the rear axle were Goodyear 18.4-30R1, load capability $19.12 \mathrm{kN}$ and tread height of $0.035 \mathrm{~m}$, tires on the front axle were Fate 12.4-24R1, load capability $12.60 \mathrm{kN}$ and tread height of $0.030 \mathrm{~m}$. The worn tire set on the rear axle was Pirelli 18.4-30R1, load capability 19.12 $\mathrm{kN}$ and average tread height of 0.0048 , and on the front axle Firestone 12.4-24R1, load capability $11.7 \mathrm{kN}$ and tread height of $0.018 \mathrm{~m}$.

The three inflation pressure levels used in the rear and front tires were respectively: pressure 1 (P1): $180 \mathrm{kPa}$ (26 psi) and $165 \mathrm{kPa}$ (24 psi), pressure $2(\mathrm{P} 2): 138 \mathrm{kPa}(20 \mathrm{psi})$ and $125 \mathrm{kPa}(18$ psi) and pressure $3(\mathrm{P} 3): 110 \mathrm{kPa}$ (16 psi) and 83 $\mathrm{kPa}(12 \mathrm{psi})$.

This study was carried out with the tractor operating in three ballast conditions: ballast 1 (L1): tires with water occupying $75 \%$ of the volume and with metallic ballast, ballast 2 (L2): tires with water occupying $75 \%$ of volume and no metallic ballast, and ballast 3 (L3): tires without water or metallic ballast. The metallic elements corresponded to six front links and two lateral rings coupled to the center of the rear shaft; the masses of each metallic element were 35 and $65 \mathrm{~kg}$, respectively. The total tractor weight in static conditions for the three ballast conditions are the following: L1: $45.24 \mathrm{kN}$ (4610 kgf), corresponding to $100 \%$ of the tractor weight; L2: $41.87 \mathrm{kN}$ (4270 kgf), corresponding to $92.55 \%$ of total tractor weight; and L3: $33.56 \mathrm{kN}$ (3422 kgf), equivalent to $74.18 \%$ of total tractor weight.

Spinning was measured from observation of the time necessary to displace the driven tractor in each area, before and after the application of the load on the tractor brake; the difference between times characterizes the spinning of the driven tractor when the loading is applied. It was calculated according to the equation below: 
$\mathrm{P}_{(\%)}=\frac{(\mathrm{t} 0-\mathrm{t} 1)}{\mathrm{t} 0} * 100$

where,

$\mathrm{P}=$ spinning $(\%)$;

$\mathrm{t}_{0}=$ time to travel 30 meters, no load (s);

$\mathrm{t}_{1}=$ time to travel 30 meters, with load (s).

For the data collection of traction force, a 50 $\mathrm{kN}$ Kyowa load cell was used, as well as a model 8 Spider signal conditioner. By means of a universal testing machine, it was possible to generate the calibration curve of the load cell, where the data collected in $\mathrm{mV}$ were transformed into $\mathrm{kW}$.

The drawbar power was calculated in function of the force applied on the drawbar and the displacement speed of the tractor, according to the equation as follows:

$P b=F t * V$

where,

$\mathrm{Pb}=$ drawbar power $(\mathrm{kW})$;

$\mathrm{Ft}=$ drawbar force $(\mathrm{kN})$;

$\mathrm{V}=$ displacement speed of the tractor $\left(\mathrm{m} \mathrm{s}^{-1}\right)$.

The traction coefficient is the relationship between the traction force on the drawbar and the dynamic load acting on the traction shafts. It represents how much of the tractor weight is transformed in drawbar force, used as a measure of the efficiency of the shaft-ground system compared to the addition of weight (ballast) to the traction shaft.

The traction coefficient is a relationship between forces, given by the equation:

$\mathrm{kt}=\frac{\mathrm{Ft}}{\mathrm{Wd}}$

where,

$\mathrm{kt}=$ traction coefficient;

$\mathrm{Ft}=$ traction force on the drawbar $(\mathrm{kN})$;

$\mathrm{Wd}=$ dynamic load on the shaft $(\mathrm{kN})$.

\section{RESULTS AND DISCUSSION}

According to the Soils Department of the UFLA, results of the particle size distribution analysis for the layer 0 to $0.3 \mathrm{~m}$ presented the mean values of
$0.16,0.18$ and $0.66 \mathrm{~kg} \mathrm{~kg}^{-1}$ for sand, silt and clay, respectively.

The cone index, for characterizing the resistance to the average penetration to the depth of $0.15 \mathrm{~m}$, was $2092.6 \mathrm{kPa}$, the soil presented an average moisture content of $25.6 \%$, and $14.97 \mathrm{t} \mathrm{ha}^{-1}$ of organic matter was encountered the moment the tests were carried out.

In Table 1 it is seen that there was no significant difference between the factors tire, ballast and pressure, with respect to drawbar force and the traction coefficient. It is also noted that the interactions between pressure and ballast regarding spinning presented no significant difference. For comparison between tires, greater spinning was observed for new tires compared to the worn ones due to the greater development of force and drawbar power. According to Gabriel Filho et al. (2010), the tires with lower tread adhere better to the firm soil, which contributes to reduced spinning.

Regarding the other parameters studied, the use of new tires resulted in better tractor performance compared to the use of worn tires, agreeing with the study of Miranda et al. (2000).

In order to better state the analysis of variance results presented in Table 1, it was necessary to unfold the interactions between the factors tire, pressure and ballast for spinning, drawbar force, drawbar power and traction coefficient variables.

Table 2 presents the unfolding of tire and pressure interactions. When only the new tire is analyzed, the lowest inflation pressure (P3) and intermediate pressure (P2) indices resulted in greater development of drawbar force, which was reflected in the high drawbar power and traction coefficient. These results are in accordance with those found by Charles (1984), Ferreira et al. (2000b) and Serrano (2008), who encountered greater drawbar force values when lower tire inflation pressure indices were used.

Regarding spinning of the worn tire, an increase was observed with elevated pressure, according to Table 2, which is in agreement with Ferreira (2000a) who mentioned that the tire pressure increase resulted in increased spinning when the tractor handled drawbar loads equivalent to 13.18 $\mathrm{kN}$. When worn tires were used, all the studied parameters demonstrated an increasing trend as a function of increasing pressure.

\section{REVENG}


Table 1. Analysis of variance and the mean values for spinning, drawbar force, drawbar power and traction coefficient variables

\begin{tabular}{|c|c|c|c|c|}
\hline Factors & Spinning (\%) & Drawbar Force $(\mathrm{kN})$ & Drawbar Power $(\mathrm{kW})$ & Traction Coefficient \\
\hline \multicolumn{5}{|l|}{ Tire $(\mathrm{PN})$} \\
\hline New & $20.10 \mathrm{a}$ & $19.58 \mathrm{a}$ & $17.01 \mathrm{a}$ & $0.49 \mathrm{a}$ \\
\hline Worn & $11.94 \mathrm{~b}$ & $15,84 \mathrm{~b}$ & $14.66 \mathrm{~b}$ & $0.39 \mathrm{~b}$ \\
\hline \multicolumn{5}{|l|}{ Pressure $(\mathrm{P})$} \\
\hline $180 / 165 \mathrm{kPa}$ & $16.39 \mathrm{ab}$ & $17.56 \mathrm{ab}$ & $15.81 \mathrm{a}$ & $0.44 \mathrm{ab}$ \\
\hline $138 / 125 \mathrm{kPa}$ & $17.38 \mathrm{a}$ & $18.58 \mathrm{a}$ & $16.22 \mathrm{a}$ & $0.46 \mathrm{a}$ \\
\hline $110 / 83 \mathrm{kPa}$ & $14.28 \mathrm{~b}$ & $16.99 \mathrm{~b}$ & $15.48 \mathrm{a}$ & $0.42 \mathrm{~b}$ \\
\hline \multicolumn{5}{|l|}{ Ballast (L) } \\
\hline $100 \%$ & $14.66 \mathrm{~b}$ & $19.73 \mathrm{a}$ & $17.83 \mathrm{a}$ & $0.44 \mathrm{~b}$ \\
\hline $92,55 \%$ & $15.63 \mathrm{ab}$ & $17.35 \mathrm{~b}$ & $15.58 \mathrm{~b}$ & $0.41 \mathrm{~b}$ \\
\hline $74,18 \%$ & $17.77 \mathrm{a}$ & $16.06 \mathrm{~b}$ & $14.09 \mathrm{c}$ & $0.48 \mathrm{a}$ \\
\hline \multicolumn{5}{|l|}{ F Test } \\
\hline PN & $87.10 * *$ & $70.25 * *$ & $53.62 * *$ & $71.84 * *$ \\
\hline $\mathrm{P}$ & $4.36 *$ & $4.38 *$ & $1.79 \mathrm{~ns}$ & $3.76 *$ \\
\hline $\mathrm{L}$ & $4.41 *$ & $23.21 * *$ & $45.77 * *$ & $10.27 * *$ \\
\hline PN X P & $5.92 * *$ & $10.98 * *$ & $9.88 * *$ & $9.63 * *$ \\
\hline PN X L & $11.57 * *$ & $8.36 * *$ & $7.08 * *$ & $11.64 * *$ \\
\hline PX L & $0.44 \mathrm{~ns}$ & $5.96 * *$ & $9.02 * *$ & $5.20 * *$ \\
\hline PN X P X L & $0.11 *$ & $1.80 \mathrm{~ns}$ & $2.92 *$ & $1.67 \mathrm{~ns}$ \\
\hline CV (\%) & 20.0 & 9.2 & 7.4 & 9.7 \\
\hline
\end{tabular}

For each factor, means followed by the same lowercase letter in the column do not differ by the Tukey test, at $5 \%$ probability, and means followed by no letter imply an interaction between factors

ns - Non-significant $(p>0.05) ; *$ - Significant $(p<0.05) ; * *$ - Significant $(p<0.01)$; C.V. - Coefficient of variations - Insignificant $(\mathrm{p}>0.05)$

Table 2. Unfolding of the interaction between the factors tire and inflation pressure for spinning, traction force on the drawbar, drawbar power and traction coefficient

\begin{tabular}{|c|c|c|c|}
\hline \multirow{2}{*}{ Tire } & \multicolumn{3}{|c|}{ Inflation Pressure } \\
\hline & $180 / 165 \mathrm{kPa}$ & $138 / 125 \mathrm{kPa}$ & $110 / 83 \mathrm{kPa}$ \\
\hline \multicolumn{4}{|c|}{ Spinning (\%) } \\
\hline New & $18.35 \mathrm{aB}$ & $22.38 \mathrm{aA}$ & $19.55 \mathrm{aAB}$ \\
\hline Worn & $14.44 \mathrm{bA}$ & $12.37 \mathrm{bAB}$ & $9.01 \mathrm{bB}$ \\
\hline \multicolumn{4}{|c|}{ Traction Force $(\mathrm{kN})$} \\
\hline New & $17.96 \mathrm{aB}$ & $21.15 \mathrm{aA}$ & $19.63 \mathrm{aAB}$ \\
\hline Worn & $17.17 \mathrm{aA}$ & $16.01 \mathrm{bAB}$ & $14.35 \mathrm{bB}$ \\
\hline \multicolumn{4}{|c|}{ Drawbar Power $(\mathrm{kW})$} \\
\hline New & $15.98 \mathrm{aB}$ & $17.77 \mathrm{aA}$ & $17.28 \mathrm{aAB}$ \\
\hline Worn & $15.63 \mathrm{aA}$ & $14.67 \mathrm{bAB}$ & $13.67 \mathrm{bB}$ \\
\hline \multicolumn{4}{|c|}{ Traction Coefficient } \\
\hline New & $0.46 \mathrm{aB}$ & $0.53 \mathrm{aA}$ & $0.49 \mathrm{aAB}$ \\
\hline Worn & $0.43 \mathrm{aA}$ & $0.40 \mathrm{bAB}$ & $0.35 \mathrm{bB}$ \\
\hline
\end{tabular}

In each lumn, mean values lowed by the same ercase letter and, in each line, mean values lowed by the same apital letter do not differ rding to the Tukey test, at $5 \%$ bility. 
When using diagonal-treaded tires without water or when filled up to $37.5 \%$, in soil conditions with mulching, Monteiro et al. (2011) found higher spinning values for tires with $75 \%$ of their volume filled with water, which verifies the results found in the present test campaign (Table 3), in which the lowest ballast index (L3) presented the greatest spinning values with an average of $24.81 \%$ when new diagonal tires were used. This increase in spinning resulted from the reduction of displacement speed of the tractor and consequently drawbar power reduction, while the new tire treatments demonstrated the increasing trend of drawbar power according to the increase in spinning indices, in agreement with Palma et al. (2010) who stated that the drawbar power tends to increase with spinning until reaching a maximum level, followed by a decrease while spinning further increases.

Table 3. Unfolding of the interaction between the factors tire and ballast for spinning, traction force on the drawbar, drawbar power and traction coefficient

\begin{tabular}{|c|c|c|c|}
\hline \multirow{2}{*}{ Tire } & \multicolumn{3}{|c|}{ Ballast } \\
\hline & $100 \%$ & $92.55 \%$ & $74.18 \%$ \\
\hline \multicolumn{4}{|c|}{ Spinning $(\%)$} \\
\hline New & $17.39 \mathrm{aB}$ & $18.09 \mathrm{aB}$ & $24.81 \mathrm{aA}$ \\
\hline Worn & $11.93 \mathrm{bA}$ & $13.17 \mathrm{bA}$ & $10.72 \mathrm{bA}$ \\
\hline \multicolumn{4}{|c|}{ Traction Force $(\mathrm{kN})$} \\
\hline New & $20.35 \mathrm{aA}$ & $19.55 \mathrm{aA}$ & $18.84 \mathrm{aA}$ \\
\hline Worn & $19.10 \mathrm{aA}$ & $15.16 \mathrm{bB}$ & $13.27 \mathrm{bC}$ \\
\hline \multicolumn{4}{|c|}{ Drawbar Power $(\mathrm{kW})$} \\
\hline New & $18.16 \mathrm{aA}$ & $17.23 \mathrm{aA}$ & $15.65 \mathrm{aB}$ \\
\hline Worn & $17.51 \mathrm{aA}$ & $13.94 \mathrm{bB}$ & $12.52 \mathrm{bC}$ \\
\hline \multicolumn{4}{|c|}{ Traction Coefficient } \\
\hline New & $0.45 \mathrm{aB}$ & $0.47 \mathrm{aB}$ & $0.56 \mathrm{aA}$ \\
\hline Worn & $0.42 \mathrm{aA}$ & $0.36 \mathrm{bB}$ & $0.40 \mathrm{bAB}$ \\
\hline
\end{tabular}

In each lumn, mean values lowed by the same ercase letters and, in each line, mean values lowed by the same apital letter do not differ rding to the Tukey test, at $5 \%$ ability.
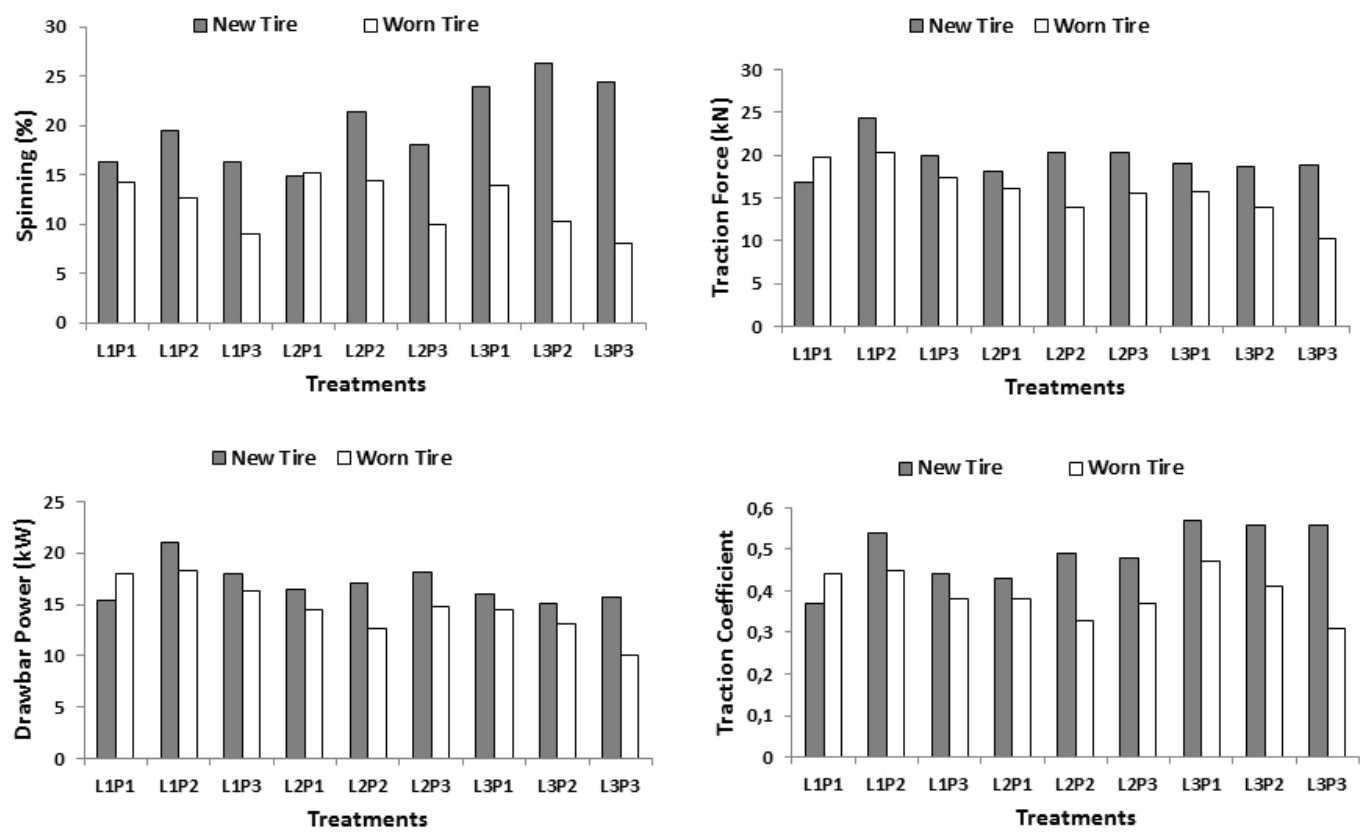

Figure 1. Comparison of the indices of spinning, drawbar force, drawbar power and traction coefficient when new and worn tires were used. 
The greatest traction coefficient was found for the new tire with the lowest ballast (Figure 1), a fact that corroborates with Yanai (1999); this is due to the fact that this coefficient is calculated by the relationship between drawbar force and tractor weight. In this case, the forces on the drawbar when the lowest ballast was used were similar to the forces found when using higher ballast levels; therefore the increase in the denominator of the equation, in this case the weight, resulted in an increase in the traction coefficient.

The use of worn tires resulted in an increase in drawbar force in function of the increase in ballast levels, which agrees with Charles (1984).

From Figure 1 it can be observed that the interaction (L1P2), in which the tractor was ballasted and its tires filled with $75 \%$ of their volume with water, combined with an inflation pressure of 138 and $125 \mathrm{kPa}$ in the rear and front tires respectively, the drawbar force and power presented their greatest values. The smallest values of drawbar force and power were found when the smallest indices of pressure and L3P3 ballast were used, regardless of tire type. Figure 1 also shows that certain levels of pressure and ballast are more favorable for the development of greater drawbar force and power, as well as a greater traction coefficient.

\section{CONCLUSIONS}

- The behavior of new tires, within the studied parameters and conditions, was better than that of worn tires, with the exception of spinning. Greater spinning indices ocurred when new tires were used due to their greater capability to develop drawbar force and power;

- When worn tire were used, treatments L1P1 and L1P2, the tractor presented better force and power conditions on the drawbar. Meanwhile, when the new tire was used, the L1P2 treatment yielded greater values of drawbar force, drawbar power and traction coefficient;

- Greater indices of ballast yielded better traction conditions for the tractor when worn tires were used;

- For a compacted soil with mulching, the use of worn tires is an alternative for operations that require little drawbar force and power.

\section{REFERENCES}

BARBOSA, J.A.; VIEIRA, L.B.; DIAS, G.P.; DIAS JUNIOR, M.S. Desempenho operacional de um trator agrícola equipado alternadamente com pneus radiais e diagonais. Revista Engenharia Agrícola, Jaboticabal, v.25, n.2, p.474-480, 2005.

CHARLES, S.M. Effects of ballast and inflation pressure on tractor tire performance. Agricultural Engineering, v.65, n.2, p.11-13, Feb. 1984.

CORRÊA, I.M.; YANAI, K.; MAZIEIRO, J.V.G.; MOLINA JR, W.E. Agricultural tractor equipped with low-pressure tires and bias ply: comparative performance. Agro-Ciencia. v.13, p.319-323, Oct-Dic. 1997.

DWYER, M.J.; FEBO, P. Handbook of agricultural tyre performance. Silsoe: Institut of Engineering Research, 1987. 16p. (report, 47. AFRC)

FERREIRA, M.F.; SCHLOSSER, J.F.; NEUJAHR, E.B. Patinamento de pneus diagonais de um trator $4 \times 2$ em função da variação da pressão interna e carga na barra de tração. Revista Brasileira de Agrociência, Pelotas, RS, v.6, n.3, p.254-257, 2000 a.

FERREIRA, M.F.; NEUJAHR, E.B.; SCHLOSSER, J.F.; SHNEIDER, V. Influência da pressão interna em pneus diagonais na força de tração de um trator $4 \times 2 \mathrm{em}$ duas condições de superfície. Revista Brasileira de Agrociência, Pelotas, RS, v.6, n.1, p.66-70, 2000 b.

GABRIEL FILHO, A.; MONTEIRO, L. de A.; LANÇAS, K.P.; GUERRA, S.P.S; JESUINO, P.R. Influência da altura das garras dos pneus de um trator em área de plantio direto. Revista Brasileira de Engenharia Agrícola e Ambiental, Campina Grande, v.14, n.10, 2010.

GABRIEL FILHO, A.; SILVA, S.L.; MODOLO, A.J.; DA SILVEIRA, J.C.M. Desempenho de um trator operando em solo com diferentes tipos de cobertura vegetal. Revista Engenharia Agrícola, Jaboticabal, SP, v.24, n.3, p.781-789, 2004.

GEE-CLOUGH, D.; MCALLISTER, M.; EVERDEN, D.W. Tractive performance of tractor drive tires II. A comparison of radial and crossply carcass construction. Journal of Agricultura 
Engineering Research, Silsoe, v.22, n.4, p.385395, 1977.

MONTEIRO, L. de A.; LANCAS, K.P.; GUERRA, S.P.S. Desempenho de um trator agrícola equipado com pneus radiais e diagonais com três níveis de lastros líquidos. Revista Engenharia Agrícola, Jaboticabal, v.31, n.3, 2011.

PALMA, M.A.Z.; VOLPATO, C.E.S.; BARBOSA, J.A.; SPAGNOLO, R.T.; BARROS, M.M.; VILAS BOAS, L.A. Efeito da profundidade de trabalho das hastes sulcadoras de uma semeadora-adubadora na patinagem, na força de tração e no consumo de combustível de um trator agrícola. Revista Ciência e Agrotecnologia, Lavras, vol.34, n.5, p.1320-1326, 2010.

SALVADOR, N.; MION, R.L.; BENEZ, S.H. Consumo de combustível em diferentes sistemas de preparo periódico realizados antes e depois da operação de subsolagem. Revista Ciência e Agrotecnologia, Lavras, v.33, n.3, p.870-874, 2009.

SERRANO, J.M.P.R. Pressão de insuflagem dos pneus no desempenho do conjunto trator-grade de discos. Pesquisa Agropecuária Brasileira,
Brasília, v.43, n.2, p.277-233, 2008.

SERRANO, J.M.; PEÇA, J.O.; PINHEIRO, A.; CARVALHO, M.; NUNES, M.; RIBEIRO, L.; SANTOS, L. Ensaios de campo de tracção: Contribuição para a optimização do desempenho do tractor agrícola. Gazeta das Aldeias, v.3096, p.29-36, 2003.

ŠMERDA, T.; ČUPERA, J. Tire inflation and its influence on drawbar characteristics and performance - Energetic indicators of a tractor set. Journal of Terramechanics, v.47, n.6, p.395-400, 2010.

SPAGNOLO, R.T.; VOLPATO, C.E.S.; BARBOSA, J.A. ; PALMA, M.A.Z. ; BARROS, M.M. . Consumo de combustível de um trator em função do desgaste, da lastragem e pressão de insuflação dos pneus. Revista Engenharia Agrícola, v.32, p.12, 2012.

YANAI, K.; SILVEIRA, G.M.; LANÇAS, K.P.; CORRÊA, I.M.; MAZIERO, J.V.G. Desempenho operacional de trator com e sem o acionamento da tração dianteira auxiliar. Pesquisa Agropecuária Brasileira, v.34, n.8, p.1427-1434, 1999. 